\title{
A Collagenolytic System Produced by Primary Cultures of Rheumatoid Nodule Tissue
}

\author{
EdWard D. Harris, JR. \\ From the Department of Medicine, Dartmouth/Hitchcock Medical Center \\ Hanover, New Hampshire 03755
}

A B S T R A C T A collagenase and a neutral protease have been insolated and characterized from primary cultures obtained from rheumatoid subcutaneous nodules. Release of both active enzymes was maximal between the 3rd and 7th days of culture and was stimulated by the presence of small amounts of colchicine $(0.1 \mu \mathrm{g} / \mathrm{ml})$ added to the culture medium.

Both the protease and the collagenase from nodule tissue were active at physiologic $\mathrm{pH}$ and were inhibited by chelating agents, sulfhydryl compounds, and 1:40 dilutions of human serum. Both enzymes appeared to have a molcular size equivalent to similar enzymes found in cultures of rheumatoid synovium. The nodule collagenase was purified by chromatography on molecular sieve columns followed by affinity chromatography. The pure enzyme cleaved collagen in solution at $24^{\circ} \mathrm{C}$ at the locus common for mammalian collagenases to act: three quarters of the distance from the amino-terminus. Under the same conditions the purified enzyme cleaved gelatin (denatured collagen) at the same locus. It is likely therefore that the collagenase in rheumatoid connective tissues functions to produce the initial cleavage of collagen and that after the initial reaction products are denatured, proteases digest them into smaller polypeptides more rapidly than does the collagenase itself.

Since rheumatoid nodules grow centrifugally at the expense of the palisading fibroblast layer it seems possible that the central necrotic areas are caused by release of collagenase and protease from the highly cellular palisading zone resulting in the destruction of the extracellular collagen matrix.

Presented at the Dermatology subspecialty meeting jointly sponsored by the American Federation for Clinical Research and the American Society for Clinical Investigation, Atlantic City, N. J., 30 April 1972.

Dr. Harris is a recipient of a Research Career Development Award AM35506.

Received for publication 30 June 1972 and in revised form 22 August 1972.

\section{INTRODUCTION}

The pathology of subcutaneous rheumatoici nodules is well documented $(1,2)$. In the well-formed nodule there is a central area of necrosis rimmed by a corona of palisading fibroblasts which in turn is surrounded by a dense proliferation of collagen along with perivascular collections of chronic inflammatory cells $(1,2)$.

Although there are data from careful histologic sections of nodules at very early stages of development which suggest that the development of the peripheral nodule, as well as the synovitis, is mediated through affected arteries to the terminal vascular bed of the tissues (3), there are few other data which provide any unifying hypothesis for the pathogenesis of both rheumatoid nodules and rheumatoid synovitis, or for the development of central necrosis in the former lesions. In addition, there are virtually no biochemical studies of rheumatoid nodules, contrasted with the many metabolic, enzymatic, and immunologic studies of rheumatoid synovium and synovial fluid.

Since the mesenchymal cells of rheumatoid synovium seem to be capable of synthesizing and releasing in vitro (4-7) and in vivo $(8,9)$ specific collagenolytic enzymes which may have a primary role in the mechanism of articular destruction in rheumatoid arthritis $(10,11)$, we searched for collagenolytic enzyme production in primary cultures of rheumatoid nodules, using the same techniques that have been applied to synovium.

\section{METHODS}

Patients and handling of specimens. Nodule tissue was removed from the olecranon bursae of two female patients in whom they were causing discomfort. Both patients had classic, seropositive rheumatoid arthritis. In neither was there skin ulceration over the nodules. All tissue cultures were initiated within $1 \mathrm{hr}$ after nodule excision using sterile precautions. The dense fibrous capsule of each nodule was incised. Fluid from the necrotic centers of each nodule was discarded. Firm tissue bordering on the central necrotic areas but not including the tough, dense outer capsule was 
cut into approximately $2 \times 2-\mathrm{mm}$ pieces and cultured in vitro using techniques similar to those used for short-term cultures of synovial tissue $(4,7)$. Samples of the cultured tissue were fixed and sectioned for microscopic examination and were then stained. Colchicine (U.S.P., Eli Lilly and Company, Indianapolis, Minn.) was added to the medium in one-half of the flasks at a concentration of $0.1 \mu \mathrm{g} / \mathrm{ml}$. Medium was changed at least every other day. After 9 days of culture the tissue was harvested and the DNA content in each group of flasks was determined (12).

Assay procedures. Collagenolytic activity was assayed using substrates of guinea pig collagen in solution at $20-24^{\circ} \mathrm{C}$ and ${ }^{14} \mathrm{C}$-labeled collagen which had been reconstituted at $37^{\circ} \mathrm{C}$ to form native fibrils as described earlier (8). Neutral protease activity was determined using the same ${ }^{14} \mathrm{C}$-labeled collagen after it had been denatured to gelatin (7). Caseinolytic activity (13) and protein concentration (14) were measured in some samples.

Enzyme purification. Pooled tissue culture medium was concentrated using Aquacide and applied to a column $(1.5 \times$ $55 \mathrm{~cm}$ ) of Bio-Gel A-1.5 (Bio-Rad Laboratories, Richmond, Calif.) equilibrated with $0.1 \mathrm{M}$ Tris- $\mathrm{HCl}, \mathrm{pH} 7.6,0.005 \mathrm{~m}$ $\mathrm{CaCl}_{2}$. Fractions containing peaks of protease and collagenase activity were pooled separately and then subjected to chromatography on a column $(1.0 \times 165 \mathrm{~cm})$ of Sephadex G 150 . Fractions containing collagenase activity were pooled and concentrated.

Affinity chromatography. Sepharose 4B (Pharmacia) was activated by cyanogen bromide as described by Cuatrecasas, Wilchek, and Anfinsen (15) and was bound to collagen in

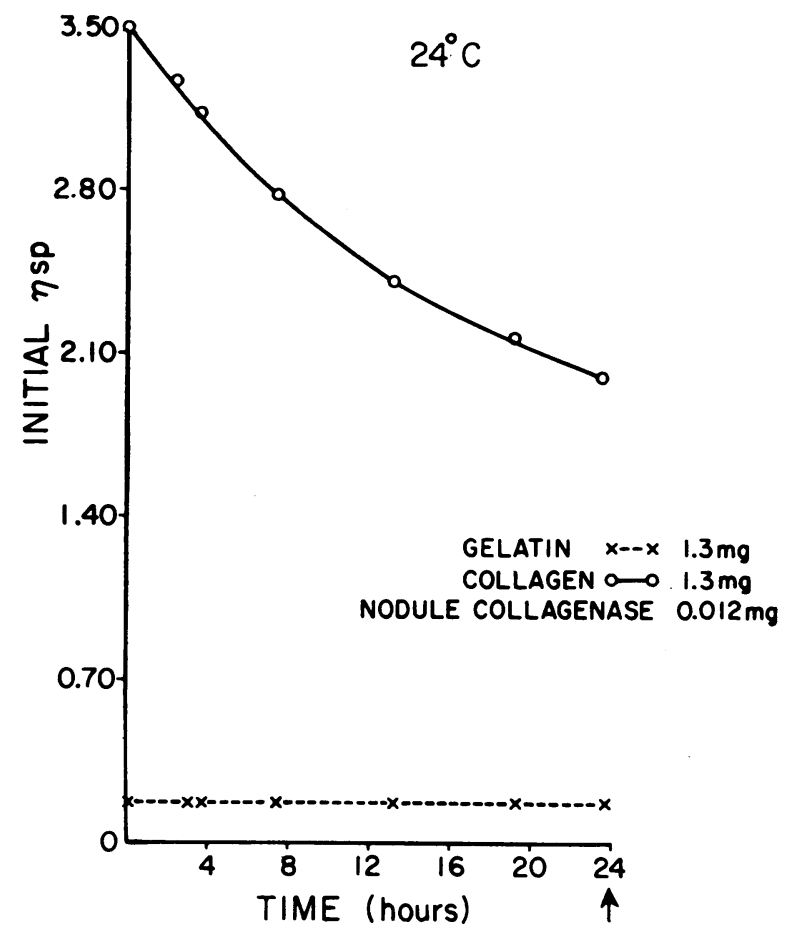

Figure 1 Viscosity changes during incubation of gelatin and collagen with purified rheumatoid nodule collagenase. Specific viscosity

$$
(\eta \mathrm{sp})=\eta \text { rel }-1 ; \eta \text { rel }=\frac{\text { sample time }}{\text { water time }}
$$

solution (purified as described previously [7]) using the technique of Bauer, Eisen, and Jeffrey (9). The Sepharosecollagen was washed and then equilibrated with $0.05 \mathrm{M}$ Tris$\mathrm{HCl}, \mathrm{pH} 7.6,0.005 \mathrm{M} \mathrm{CaCl}_{2}$ at $4^{\circ} \mathrm{C}$, as was the enzyme. The enzyme was applied to a $1 \times 4 \mathrm{~cm}$ column of the Sepharose-collagen. After washing the column with 10 bedvolumes of the starting buffer, collagenase was eluted with $1.0 \mathrm{M} \mathrm{NaCl}$ in $0.05 \mathrm{M}$ Tris $\mathrm{HCl}, \mathrm{pH} 7.6,0.005 \mathrm{M} \mathrm{CaCl}_{2}$.

Miscellaneous. Enzyme inhibitors were purchased from Sigma Chemical Co. (St. Louis, Mo.) and from Calbiochem (Los Angeles, Calif.). Acrylamide disc gel electrophoresis was carried out by the methods of Davis ( $\mathrm{pH} \mathrm{8.3)} \mathrm{(16)}$ and Nagai, Gross, and Piez (17). Segment-long-spacing (SLS) aggregates of intact collagen and of the enzymatic digestion products were prepared as described previously (8), except that the SLS formation was initiated by dialyzing samples against adenosine triphosphate (ATP) rather than by addition of ATP to the samples. Specimens prepared on carbon-coated grids were examined and photographed by Dr. Charles Faulkner using a Siemens Elmiskop IA electron microscope (Siemens Corp., Iselin, N. J.). Use of a Gilford gel scanner (Gilford Instrument Laboratories, Inc., Oberlin, Ohio) was kindly provided by Leonard Malkin and Rhona Mirsky.

\section{RESULTS}

Histologic examination of the nodules cultured in these studies showed classic changes of central necrosis and a dense cellular layer arranged radially. This layer gradually became less cellular at the periphery where the cells and collagen assumed a circumferential orientation and where there were small foci of perivascular lymphocytes.

During the first 3 days of culture no significant amounts of collagenolytic activity were found in the medium from either control or colchicine-treated tissue. ${ }^{1}$ However, from the 3 rd through the 7 th days of culture considerable collagenolytic activity was found in the medium in the tissues from both patients. The colchicinecontaining medium from one set of cultures had collagenolytic activity calculated at $15,000 \mathrm{dpm} / \mathrm{mg}$ DNA per $\mathrm{hr}$, while enzyme from the medium not containing colchicine degraded substrate at a rate of $8,000 \mathrm{dpm} / \mathrm{mg}$ DNA per hr. The medium from eight rheumatoid synovial cultures were assayed using the same substrate and only one quarter to one-third as much collagenolytic activity was found. The increase in activity related to the presence of colchicine in the medium was similar to that seen in the synovial cultures.

When the pooled, concentrated crude collagenolytic activity was passed through a column of Bio-Gel A 1.5, collagenase activity was eluted in the area corresponding to $20,000-40,000$ daltons. $95 \%$ of the enzyme activity was present in $8 \%$ of the initial protein applied to the column. Protease activity was eluted in a broad peak closer to the void volume of the column. After the pooled

\footnotetext{
${ }^{1}$ The colchicine had been added because of our previous observations that small concentrations $(0.1 \mu \mathrm{g} / \mathrm{ml})$ of this compound stimulate synthesis of collagenase (6) and protease ( 7 ) by rheumatoid synovial tissue.
} 
protease and collagenase peaks were passed through the Sephadex G 150 column, there was no collagenolytic activity found in the protease fractions, and negligible protease in the collagenase. The partially purified collagenase was then subjected to affinity chromatography and a total of $50 \mu \mathrm{g}$ of protein containing collagenolytic activity was isolated. $25 \mu \mathrm{g}$ of this ran as a single, faint band when subjected to acrylamide disc gel electrophoresis $(7.5 \%$ acrylamide, $\mathrm{pH} 8.3$ ). The remainder was divided into two, $12-\mu \mathrm{g}$ portions, each in $0.1 \mathrm{ml}$ of $0.1 \mathrm{~m}$ Tris- $\mathrm{HCl}$, $\mathrm{pH} 7.6,0.005 \mathrm{M} \mathrm{CaCl}_{2}$ in $10 \%$ glycerol. One portion was added to $1.3 \mathrm{mg}$ collagen in $0.9 \mathrm{ml} 0.1 \mathrm{~m}$ Tris- $\mathrm{HCl}, \mathrm{pH}$ 7.6, $0.005 \mathrm{M} \mathrm{CaCl}$ and $0.1 \mathrm{M} \mathrm{NaCl}$ in a Manning semimicro viscometer, and the other portion of enzyme was placed in a similar viscometer with the same amount of substrate in denatured form.

The course of the viscosity assay is shown in Fig. 1. The specific viscosity ( $\eta \mathrm{sp}$ ) of the collagen dropped to $57 \%$ of its original value in $24 \mathrm{hr}$. The $\eta \mathrm{sp}$ of the gelatin solution did not rise, indicating that there was no renaturation of the gelatin. The reactions in both viscometers were halted by the addition of EDTA $(0.1 \mathrm{M}$, $50 \mu 1$ ). Aliquot portions of the reaction products were applied to acrylamide gels for disc electrophoresis. Densitometer scans of the stained gels are shown in Fig. 2. The collagen/enzyme reaction products showed intact $\beta$ - and $\alpha$-chains as well as the $\mathrm{TC}^{\boldsymbol{\Lambda}}$ fragments and the $\mathrm{TC}^{\mathrm{B}}$ fragments. ${ }^{2}$ The site of cleavage was also demonstrated by direct visualization of TC ${ }^{\boldsymbol{A}}$ SLS and $\mathrm{TC}^{\mathrm{B}}$ SLS by electron microscopy. In the gelatin/enzyme digest, the $\mathrm{TC}^{\boldsymbol{A}} \boldsymbol{\beta}_{\text {- }}$ and $\mathrm{TC}^{\boldsymbol{A}} \boldsymbol{\alpha}$-bands were less well-defined than in the collagen/enzyme digest but the distribution indicated that about $90 \%$ of the substrate was converted into $\mathrm{TC}^{\boldsymbol{A}} \beta, \mathrm{TC}^{\boldsymbol{A}} \alpha$, and $\mathrm{TC}^{\boldsymbol{B}} ; 10 \%$ of the gelatin/collagenase reaction products ran with the buffer front, where peptide fragments of less than 10,000 daltons are found.

No differences were found in $\mathrm{pH}$ maxima (4), estimated molecular size (8), or inhibitor effects comparing the synovial enzymes (7) and the nodule enzymes (both collagenase and protease). Both collagenases, for example, were inhibited $90 \%$ by 0.01 м dithiothreitol, D-penicillamine, $\alpha, \alpha^{\prime}$-dipyridyl, and 1,10-phenanthroline, and by pooled normal human serum at $1: 40$ dilution. 1,10-phenanthroline inhibited both collagenases better at low concentrations $\left(78 \%\right.$ at $10^{-4} \mathrm{M}, 36 \%$ at $\left.10^{-5} \mathrm{M}\right)$ than did the other inhibitors. Cysteine and L-histidine inhibited

\footnotetext{
${ }^{2} \alpha$-Chains are the basic polypeptide component of collagen ; $3 \alpha$-chains comprise one collagen molecule. $\beta$-Chains are 2 $\alpha$-chains joined by a covalent cross-link near the aminoterminus. Thus, cleavage of intact collagen by mammalian collagenases at the locus $75 \%$ from the amino-terminus produces $\mathrm{TC}^{\Delta} \boldsymbol{\alpha}$ and $\mathrm{TC}^{\boldsymbol{\Delta}} \boldsymbol{\beta}$ from $\alpha$ - and $\beta$-chains, respectively, and the carboxyterminal $\mathrm{TC}^{\mathrm{B}}$ fragment from both $\alpha$ - and $\beta$-chains.
}

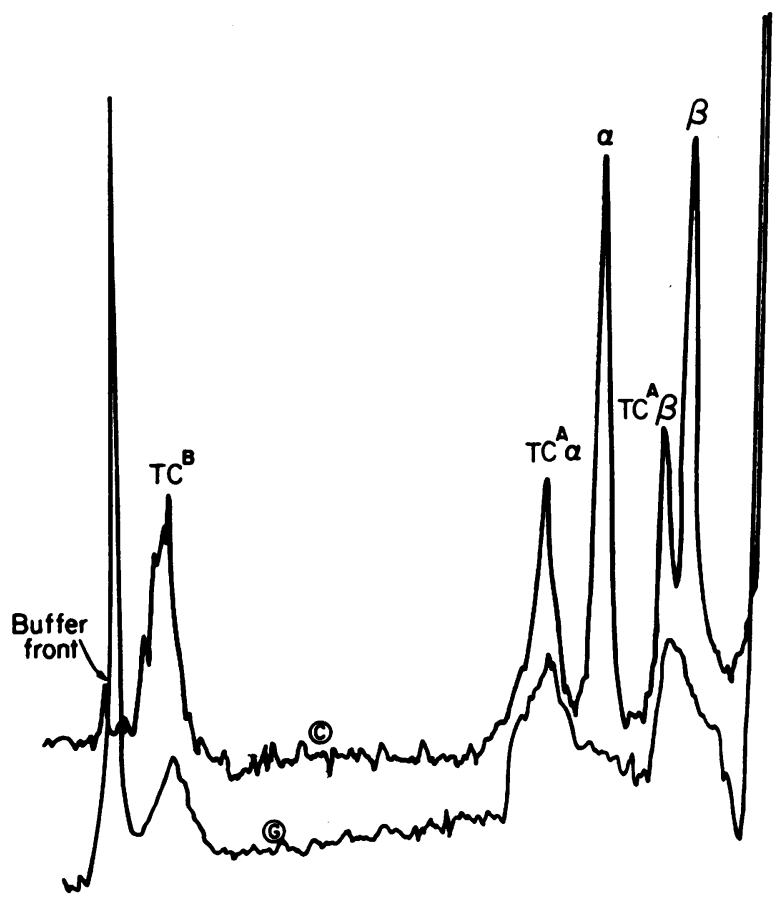

FIgURE 2 Densitometer scans after acrylamide gel electrophoresis of the reaction products from viscometric assays shown in Fig. 1. Line $\mathrm{C}$ is collagen/collagenase reaction products. Line $G$ is the gelatin/collagenase mixture. Note that the $G$ gel had broad, diffuse bands which nevertheless had peak density in areas corresponding to $\mathrm{TC}^{\boldsymbol{\Delta}} \beta$, $\mathrm{TC}^{\boldsymbol{A}} \alpha$, and $\mathrm{TC}^{\mathbf{B}}$. Material staining at the buffer front represents gelatin fragments of $<10,000$ daltons.

both enzymes to $60 \%$ of control values at $10^{-2}$ concentrations.

\section{DISCUSSION}

Previous studies of rheumatoid synovial tissue (7) showed that the collagenase partially purified from primary cultures of these tissues had little capacity to degrade gelatin to fragments of $<10,000$ daltons while the neutral protease found in those same cultures readily digested gelatin to fragments of about 5,000 daltons. In the present studies, highly purified rheumatoid nodule collagenase did not degrade gelatin significantly more than it degraded native collagen. Our hypothesis is that, in vivo, after the initial cleavage of collagen into two fragments by collagenase and the postulated spontaneous denaturation of these fragments at $37^{\circ} \mathrm{C}$ to gelatin fragments (10), subsequent breakdown of these primary products of collagenolysis is accomplished by proteases.

It is likely that there are no significant differences between the collagenolytic system produced by rheumatoid synovial and nodule tissues. In all ways tested, the two nodule enzymes were similar to the collagenase and protease found in synovial cultures $(4,7)$. It is unlikely that 
we have isolated enzymes which are present in normal subcutaneous tissue. Using primary cultures similar to ours, Eisen found negligible collagenolytic activity in the lower dermis and subcutaneous tissue of human skin (18).

A role in the pathogenesis of articular destruction in rheumatoid arthritis has been proposed for the synovial enzymes (11); similarly, it is possible that the collagenolytic enzyme system contributes to the central necrosis which develops in rheumatoid nodules. The rheumatoid nodule has been thought to grow by extension of the central necrotic area at the expense of the palisade layer of cells which recedes centrifugally. Collagen fragments have been identified by electron microscopy as comprising a large part of the necrotic center of these nodules (19). Perhaps the enzymes described here released by the palisading layer of cells are sufficient to result in destruction of the extracellular matrix collagen around the cells, leading to their death and suhsequent necrosis.

\section{ACKNOWLEDGMENTS}

I want to thank Mr. Michael Farrell and Miss Sheryl Locke for expert technical assistance. Mrs. Terry Hyde Van Brunt helped prepare the manuscript. Dr. Richard Karl removed the nodules from the patients. Doctors S. M. Krane and M. L. Tanzer offered constructive criticism of the manuscript.

This work was supported by U. S. Public Health Service grant AM14780 and by grants from the National and New Hampshire Chapters of the Arthritis Foundation and by the Easter Seal Research Foundation of the National Easter Seal Society for Crippled Children and Adults.

\section{REFERENCES}

1. Collins, D. H. 1937. The subcutaneous nodule of rheumatoid arthritis. J. Pathol. Bacteriol. 45: 97.

2. Bennett, G. A., J. W. Zeller, and W. Bauer. 1940. Subcutaneous nodules of rheumatoid arthritis and rheumatic fever: a pathologic study. Arch. Pathol. 30: 70.

2. Sokoloff, L. 1963. The pathophysiology of peripheral blood vessels in collagen diseases. In The Peripheral Blood Vessels. J. L. Orbison and D. E. Smith, editors. The Williams \& Wilkins Company, Baltimore. 297.
4. Evanson, J. M., J. J. Jeffrey, and S. M. Krane. 1968. Studies on collagenase from rheumatoid synovium in tissue culture. J. Clin. Invest. 47: 2639.

5. Lazarus, G. S., J. L. Decker, C. H. Oliver, J. R. Daniels, C. V. Multz, and H. M. Fullmer. 1968. Collagenolytic activity of synovium in rheumatoid arthritis. $N$. Engl. J. Med. 279: 914.

6. Harris, E. D., Jr., and S. M. Krane. 1971. Effects of colchicine on collagenase in cultures of rheumatoid synovium. Arthritis Rheum. 14: 669.

7. Harris, E. D., Jr., and S. M. Krane. 1972. An endopeptidase from rheumatoid synovial tissue culture. Biochim. Biophys. Acta. 258: 566.

8. Harris, E. D., Jr., D. R. DiBona, and S. M. Krane. 1969. Collagenases in human synovial fluid. J. Clin. Invest. 48 : 2104.

9. Bauer, E. A., A. Z. Eisen, and J. J. Jeffrey. 1971. Studies on purified rheumatoid synovial collagenase in vitro and in vivo. J. Clin. Invest. 50: 2056.

10. Harris, E. D., Jr., J. M. Evanson, D. R. DiBona, and S. M. Krane. 1970. Collagenase and rheumatoid arthritis. Arthritis Rheum. 13: 83.

11. Harris, E. D., Jr., D. R. DiBona, and S. M. Krane. 1971. Mechanisms of destruction of articular structures in rheumatoid arthritis. In Immunopathology of Inflammation. B. Forscher, editor. Excerpta Medica Foundation, Publishers, Amsterdam. 243.

12. Schneider, W. C. 1957. Determination of nucleic acids in tissues by pentose analysis. Methods Enzymol. 3: 680 .

13. Kunitz, M. 1947. Crystalline soybean trypsin inhibitor. II. General properties. J. Gen. Physiol. 30: 291.

14. Lowry, O. H., N. J. Rosebrough, A. L. Farr, and R. J. Randall. 1951. Protein measurement with the Folin phenol reagent. J. Biol. Chem. 193: 265.

15. Cuatrecasas, P., M. Wilchek, and C. B. Anfinsen. 1968. Selective enzyme purification by affinity chromatography. Proc. Natl. Acad. Sci. U. S. A. 61: 636 .

16. Davis, B. J. 1964. Disc electrophoresis. II. Method and application to human serum proteins. Ann. N. Y. Acad. Sci. 121 : 404.

17. Nagai, Y., J. Gross, and K. A. Piez. 1964. Disc electrophoresis of collagen components. Ann. N. Y. Acad. Sci. $121: 494$.

18. Eisen, A. Z. 1969. Human skin collagenase: localization and distribution in normal human skin. J. Invest. Dermatol. 52 : 442.

19. Cochrane, W., D. V. Davies, J. Dorling, and E. G. L. Bywaters. 1964. Ultramicroscopic structure of the rheumatoid nodule. Ann. Rheum. Dis. 23: 345. 